\title{
Clinical and cyto-histopathological study of Hansen's disease in teaching government hospital in Mahakausal Region
}

\author{
Nandwani R.R ${ }^{1}$, Krishnan M.G' ${ }^{2}$, Gupta $\mathbf{U}^{3}$, Jain $\mathbf{M}^{4}$ \\ ${ }^{1}$ Dr. Radhika Rajesh Nandwani, Assitant Professor, Department of Pathology, ${ }^{2}$ Dr. M.G. Krishnan, Associate Professor, \\ Department of Pathology, ${ }^{3}$ Dr. Usha Gupta, Professor \& Head of the Department of Dermatology, venerology and \\ Leprosy, ${ }^{4}$ Dr. Mukesh Jain, Medical officer; all authors are affiliated with NSCB, Medical College, Jabalpur, MP, India.
}

Address for Correspondence: Dr. Radhika Rajesh Nandwani, Assitant Professor, Department of Pathology, NSCB, Medical College, Jabalpur. Email id: rdhiknndwni@gmail.com

\begin{abstract}
Background: Hansen's disease still remains a significant public health problem worldwide, especially in developing countries like India. Patients suffering from Hansen's disease can remain undiagnosed for a longtime, because of long incubation period, over dependence of clinical expertise and a lack of rapid and simple diagnostic tool. Cytology is an inexpensive, rapid and accurate procedure for diagnosis of skin lesions of Hansen's disease. Aims: The aim of this prospective study was to assess the usefulness of Cytopathology in early diagnosis of Hansen's disease and to correlate the cytological smear findings with clinical and histopathological features. Methods: The study is a hospital based prospective study carried out in the Department of Pathology and Department of Skin, VD, Leprosy, N.S.C.B. Medical College \& Hospital, Jabalpur (M.P.). Patients with new skin lesions were selected for the study. Fine needle aspiration cytology was performed and aspirates were evaluated for cytology and punch biopsy was collected. Results: Out of 50 cases, most patients belonged to 20-40 yrs of age, of which $35(70 \%)$ were males and $15(30 \%)$ were females. Borderline Tuberculoid was the most frequent morphologic type seen in both sexes. The clinical and cytological correlation was seen in $88 \%$ tuberculoid leprosy, $93.7 \%$ of borderline tuberculoid, $33 \%$ of borderline lepromatous leprosy and $66 \%$ of lepromatous leprosy. While clinical with histopathological correlation revealed $100 \%$ specificity in tuberculoid leprosy, borderline tuberculoid and $100 \%$ in Histoid leprosy, $66.6 \%$ in borderline lepromatous, $83.3 \%$ in lepromatous leprosy and $80 \%$ in indeterminate leprosy in our study. Concordant results between cytology and histopathology was seen in majority of cases $(84.8 \%)$ studied. The overall cytodiagnostic accuracy has been $92 \%$. Conclusion: Our study demonstrates that FNAC is a safe, simple, rapid, less-invasive, OPD procedure for early diagnosis and classification of leprosy in majority of cases.
\end{abstract}

Keywords: Acid fast bacilli, Biopsy, Cytopathology, Mycobacterium leprae

\section{Introduction}

Hansen's disease (Leprosy), a chronic inflammatory mycobacterial disease, has long been one of the most stigmatized diseases, probably due to fear of contagion and deformities. It has tormented the human civilization through time immemorial. It still afflicts humanity, bringing new challenges and still arouses our curiosity. In spite of our knowledge about Hansen's disease, it still remains a major public health problem in many developing countries for centuries. According to WHO

Manuscript received 24 $4^{\text {th }}$ August 2016

Reviewed: $4^{\text {th }}$ September 2016

Author Corrected: $18^{\text {th }}$ September 2016

Accepted for Publication 30 $30^{\text {th }}$ September 2016 the estimated global new cases detection in 2011 was 2 , 19, 075[1] and India accounts for 1, 27, 295 (58\%) of new cases of Hansen's disease [2].

The clinical manifestations of Hansen's disease are so varied and diverse and can mimic a variety of unrelated diseases. Presentation may vary from an insignificant skin lesion to extensive disease causing profound deformities and disabilities [3]. The histopathological findings in Hansen's disease are related to the immunological status of the patient [4]. Ridley and Jopling (1966) proposed a five group histological 
classification reflecting the immunological spectrum: Tuberculoid (TT), Borderline Tuberculoid (BT), Midborderline (BB), Lepromatous Borderline (BL) and Lepromatous (LL) [5]. Later they developed clinical and bacteriological finding in each group with respective immunological and histopathological findings [6]. Clinicians have also adopted the same nomenclature for classifying Hansen's disease on clinical grounds. WHO in its $6^{\text {th }}$ technical report of 1988, classified leprosy into multibacillary and paucibacillary forms to facilitate the institution of accurate mode of therapy and regular follow-up of patients to prevent undesirable complications [7]. The diagnosis of Hansen's disease has been based on clinical criteria of anesthetic or hypoesthetic skin lesions, enlarged or thickened peripheral nerves and the presence of acid fast bacilli (AFB) in slit skin smears or tissue biopsy. The gold standard for leprosy diagnosis is histopathology examination, and it also gives information on nature of host response .Biopsy is an invasive procedure and possible only in specialized centers. To overcome this issue fine needle aspiration cytology (FNAC) of Hansen's disease lesions has emerged as a safe, simple, rapid and less traumatic technique with good diagnostic accuracy [8]. Early diagnosis of Hansen's disease is of fundamental importance for all purposes including epidemiology, case management and prevention of deformity and disability, thus requiring a multi disciplinary approach.

With this background, this study is aimed to evaluate and compare the effectiveness of cytology in early diagnosis of Hansen's disease, to identify specific cytological characteristics of diagnosis and to correlate the cytological smear patterns with histological spectrum of Hansen's disease. To evaluate merits of relatively non-invasive procedure of FNAC over more invasive procedure - biopsy in different entities of Hansen's disease for rapid, early, simpler and possible accurate diagnosis.

\section{Material and Methods}

This hospital based prospective and descriptive study was carried out in setting of Department of Pathology and Department of Skin, VD, Leprosy, N.S.C.B. Medical College \& Hospital, Jabalpur, M.P between September 2011 to September 2013. After duly signed informed consent forms and institutional ethical clearance a total of fifty clinically suspected untreated patients regardless of their age, sex, socioeconomic status and occupation were included. Previously diagnosed cases and cases already getting treatment were excluded. The clinical diagnosis was done by experienced Dermatology consultant and the investigator. History of patients was recorded. Clinical examination of skin lesions included the type, number, size, site, margins, Erythema, dryness, loss of hair and sensation and presence of neural involvement. All the cutaneous and peripheral nerves were palpated and findings like number, size, nodularity, abscess formation, tenderness and sensory or motor complaints were noted. The Hansen's disease patients were classified according to Ridley-Jopling (RJ Scale) into tuberculoid (TT), borderline tuberculoid (BT), mid-borderline (BB), borderline lepromatous (BL), and lepromatous (LL) types [5]. Apart from RJ Scale indeterminate leprosy (IL) category was also included for classification of cases.

Collection of Samples: Samples from untreated patients were collected after duly signed informed consent forms and institutional ethical clearance.

Fine needle aspiration cytology: Fine needle aspiration was done as described by Prasad PVS et al. [8]. The site was cleaned with alcohol and an assistant pinched the skin for 30 seconds to blanch the skin. A 20 mL syringe was fitted with a 21-gauge needle and the assistant created negative pressure by holding back the piston with the forefinger and index finger of the right hand. The aspirated material was transferred onto glass slides. The flat surface of another slide was used to smear the material. The aspirates were subjected to cytological examination with Hematoxylin and Eosin and Ziehl Nelson's staining. Cytological smears were assessed by two cytopathologists who were not informed about the clinical and histopathological findings. We used the cytological criteria laid down by Singh et al [9] and modified by Prasad PVS et al [8] for reporting of the FNAC smear.

Collection of Punch Biopsies: Samples for punch biopsy of approximately $4 \mathrm{~mm}$ size were collected according to standard procedures [10]. A portion of biopsy samples from each patient was fixed in $4 \%$ buffered neutral formalin and then dehydrated in a graded series of ethanol and embedded in paraffin .sections were stained with Hematoxylin and Eosin staining [H and E ]for histopathological examination. The modified Ziehl Neelsen [ZN] and Fite- Faraco [FF] stain for demonstration of AFB were used whenever required. 
Diagnostic criteria: TABLE 5

\begin{tabular}{|c|c|c|}
\hline \multicolumn{3}{|c|}{ Diagnostic cytology criteria used to classify leprosy cases by Singh et al [9] } \\
\hline Type & Cytological features & AFB stain ability \\
\hline $\begin{array}{l}\text { Tuberculoid Leprosy } \\
\text { (including TT and BT) }\end{array}$ & $\begin{array}{c}\text { Cellular smears } \\
\text { Cohesive epithelioid cell granulomas } \\
\text { Numerous lymphocytes not infiltrating the granuloma }\end{array}$ & $\begin{array}{l}\text { No stainable AFB } \\
\qquad(\mathrm{BI}=0)\end{array}$ \\
\hline $\begin{array}{l}\text { Borderline tuberculoid (BT) } \\
\text { (Modified according to Prasad } \\
\text { PVS et al) }\end{array}$ & $\begin{array}{c}\text { Cellular material with lymphocytes, histiocytes and } \\
\text { epithelioid cells } \\
\text { Foamy macrophages are a not features. }\end{array}$ & No stainable AFB \\
\hline BB(Mid-borderline leprosy ) & $\begin{array}{c}\text { Fair cellular yield } \\
\text { Poorly cohesive granulomas composed of an admixture } \\
\text { of epitheloid cells and macrophages. } \\
\text { Few lymphocytes infiltrating the granulomas }\end{array}$ & $\mathrm{BI}=1+$ to $2+$ \\
\hline $\begin{array}{l}\text { Borderline lepromatous } \\
\text { leprosy (BL) }\end{array}$ & $\begin{array}{c}\text { Moderate cellularity } \\
\text { Singly dispersed macrophages with "negative images", } \\
\text { no epitheloid cells. } \\
\text { Numerous lymphocytes (Predominant cell type) } \\
\text { diffusely admixed with macrophages }\end{array}$ & $\mathrm{BI}=3+$ to $4+$ \\
\hline Lepromatous leprosy (LL) & $\begin{array}{c}\text { Heavy cellularity } \\
\text { Numerous foamy macrophages (Predominant cell type) } \\
\text { in a fatty background with intracellular and extracellular } \\
\text { negative images. } \\
\text { Few lymphocytes }\end{array}$ & $\mathrm{BI}=5+$ to $6+($ globi $)$. \\
\hline $\begin{array}{l}\text { Erythema nodosum leprosum } \\
\text { (type II reaction in LL) }\end{array}$ & Numerous fragmented AFB $(\mathrm{MI}<1)$ and neutrophils & \\
\hline $\begin{array}{c}\text { Histoid leprosy } \\
\text { (Modified according to Prasad } \\
\text { PVS et al) } 8\end{array}$ & $\begin{array}{l}\text { Cellular yields, elongated spindle cells, scattered } \\
\text { lymphocytes. }\end{array}$ & BI 6+ \\
\hline
\end{tabular}

Data Analysis: Data was analyzed by SPSS version 10. Quantitative variables are expressed as mean \pm standard deviation and qualitative variables as percentages.

Agreement between the clinical, cytological and histopathological classification was calculated using percentage of parity. Statistical tests applied included diagnostic tests for sensitivity and specificity.

\section{Results}

The study included fifty ( $\mathrm{n}=50)$ patients clinically newly diagnosed as Hansen's disease cases were enrolled in this study. The youngest patient studied was 8 years old and the oldest was 70 years old. The mean age and standard deviation 38.06 and 16.92 years respectively [TABLE1].

Below table shows the age wise distribution of cases. Their ages ranged from were $8-70$ years with mean age 38.06 $( \pm 16.92)$ years. Most patients belong to $20-40$ years of age.

Majority of cases belongs to age group of 21 to 40 years. There were 35 (70\%) male and 15 (30\%) females. Male to female ratio was 7: 3. [TABLE 2][FIGURE 1]. On examination, 56\% cases had more than 5 lesions while $28 \%$ had single lesion.

In the present study, we observed various types of skin lesions such as macules, papules, plaques and nodules. Hypoaesthetic macular lesion were the commonest type of skin lesion observed [Pie chart 1 Pie chart 2]. 
Table 1: Distribution of cases according to age and histopathological findings.

\begin{tabular}{|c|c|c|c|c|c|c|c|c|c|}
\hline $\begin{array}{c}\text { Age } \\
\text { (Yrs.) }\end{array}$ & $\begin{array}{c}\text { Tuberculoid } \\
\text { leprosy }\end{array}$ & $\begin{array}{c}\text { Borderline } \\
\text { tuberculoid }\end{array}$ & $\begin{array}{c}\text { Mid- } \\
\text { border- } \\
\text { line }\end{array}$ & $\begin{array}{c}\text { Borderline } \\
\text { Lepromatus }\end{array}$ & $\begin{array}{c}\text { Lepromatus } \\
\text { Leprosy }\end{array}$ & $\begin{array}{c}\text { Histoid } \\
\text { Leprosy }\end{array}$ & $\begin{array}{c}\text { Indetermi } \\
\text { nate } \\
\text { leprosy }\end{array}$ & $\begin{array}{c}\text { Chronic } \\
\text { dermatitis }\end{array}$ & \begin{tabular}{c} 
Total \\
\hline$<20$
\end{tabular} \\
2 & 1 & 0 & 0 & 2 & 0 & 0 & 1 & 6 \\
\hline $20-29$ & 1 & 4 & 1 & 1 & 1 & 0 & 1 & 2 & 11 \\
\hline $30-39$ & 4 & 4 & 1 & 1 & 1 & 1 & 1 & 1 & 14 \\
\hline $40-49$ & 0 & 4 & 0 & 0 & 1 & 0 & 1 & 0 & 6 \\
\hline $50-59$ & 2 & 0 & 0 & 1 & 0 & 1 & 1 & 0 & 5 \\
\hline $60-69$ & 0 & 3 & 0 & 0 & 0 & 0 & 3 & 0 & 6 \\
\hline $70+$ & 0 & 0 & 0 & 1 & 0 & 0 & 1 & 0 & 2 \\
\hline Total & $\mathbf{9}$ & $\mathbf{1 6}$ & $\mathbf{2}$ & $\mathbf{4}$ & $\mathbf{5}$ & $\mathbf{2}$ & $\mathbf{8}$ & $\mathbf{4}$ & $\mathbf{5 0}$ \\
\hline
\end{tabular}

\section{Table 2: Distribution of cases}

\begin{tabular}{|c|c|c|c|}
\hline No. of Cases & Male & Female & Total \\
\hline Tuberculoid leprosy & 7 & 2 & 9 \\
\hline Borderline tuberculoid & 12 & 4 & 2 \\
\hline Mid-borderline & 1 & 1 & 4 \\
\hline Borderline lepromatus & 2 & 0 & 5 \\
\hline Lepromatus leprosy & 5 & 1 & 2 \\
\hline Histoid leprosy & 1 & 4 & 8 \\
\hline Indeterminate leprosy & 3 & 1 & 4 \\
\hline Chronic dermatitis & $\mathbf{3 5}(\mathbf{7 0 \%})$ & $\mathbf{1 5}(\mathbf{3 0 \%})$ & $\mathbf{5 0}$ \\
\hline Total &
\end{tabular}

There were $35(70 \%)$ male and $15(30 \%)$ females, the male female ratio of 7:3 and the mean age of male was 37.34 $( \pm 18.31)$ years and female cases was $39.73( \pm 13.55)$ years.

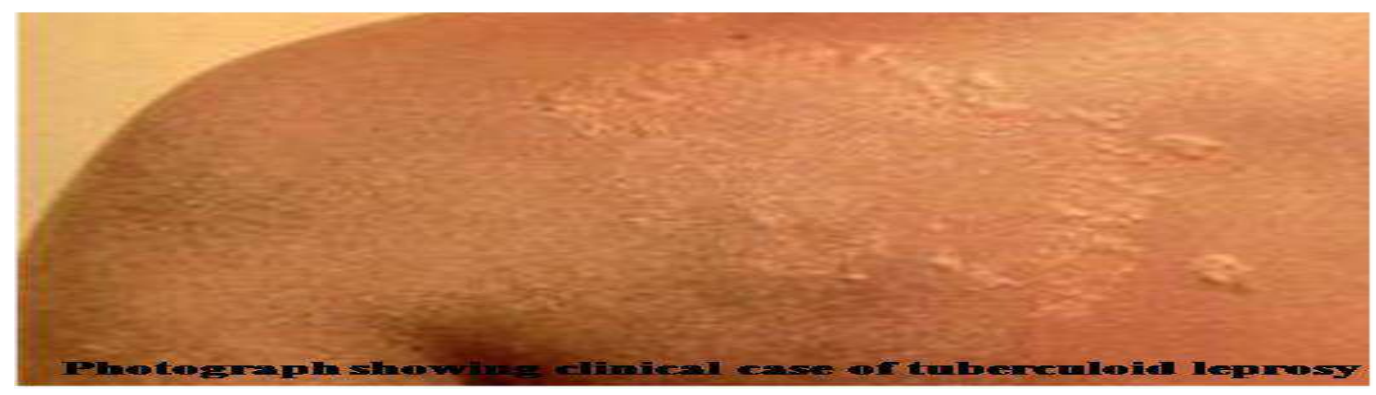

Figure- I

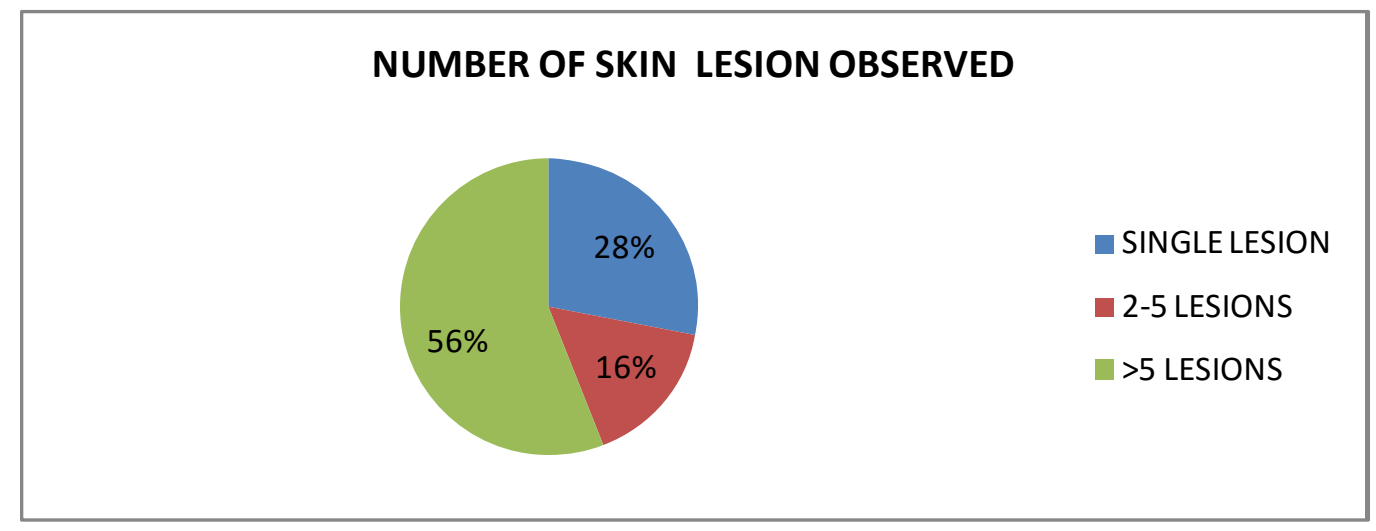

Pie chart -1 


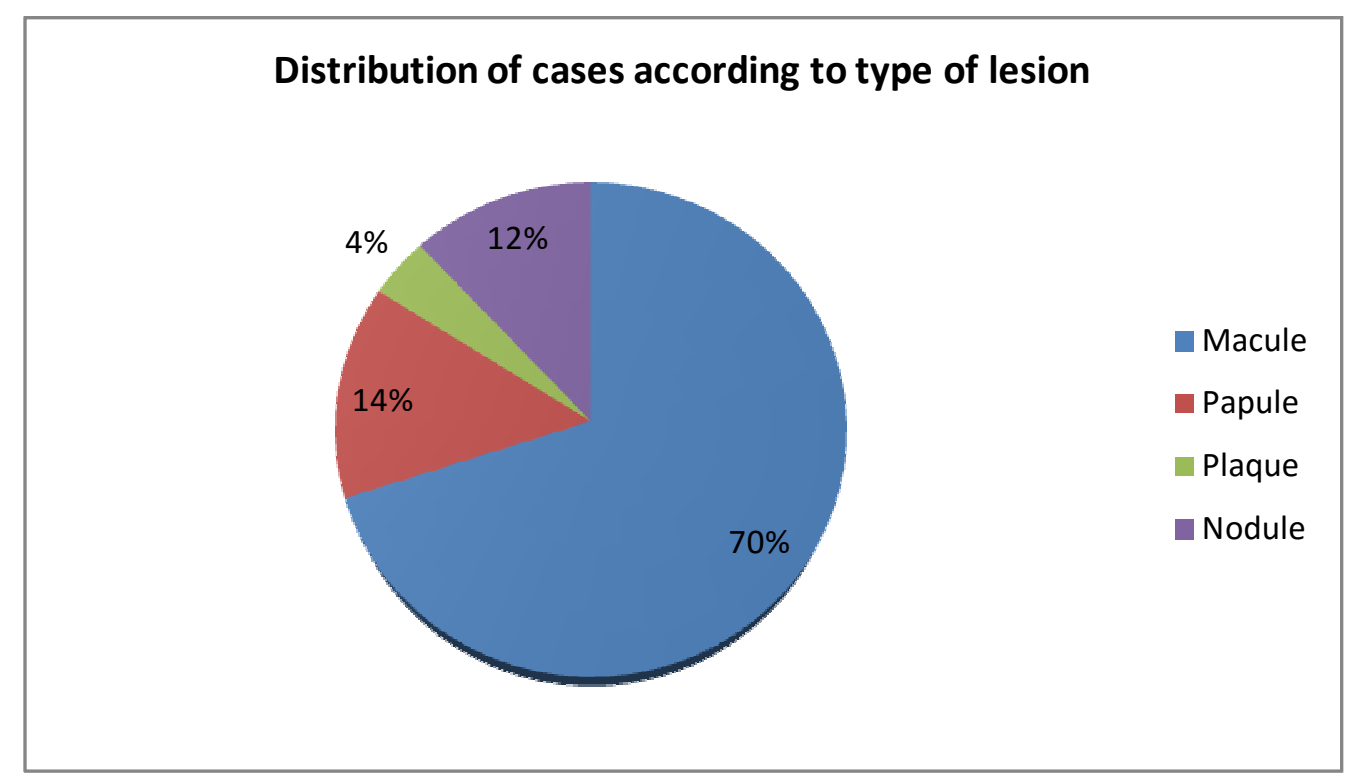

Pie chart -2
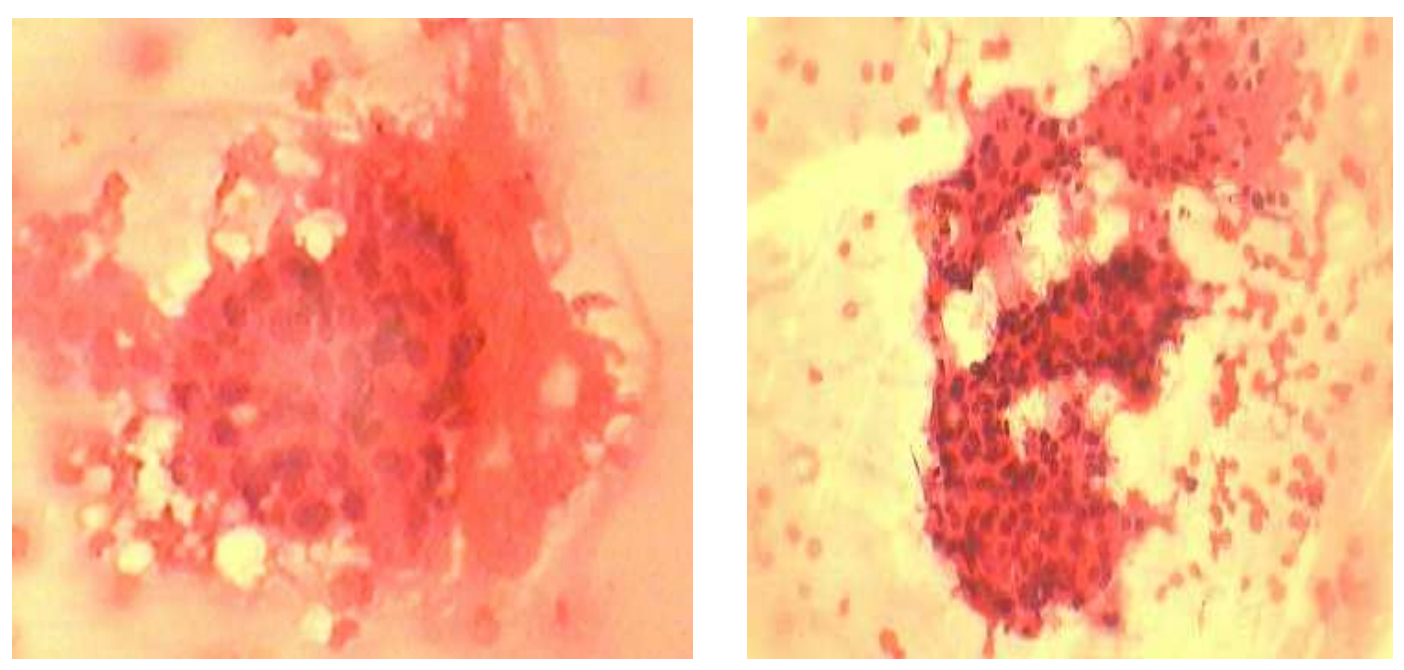

Figure-II: Cellular smear of tuberculoid leprosy

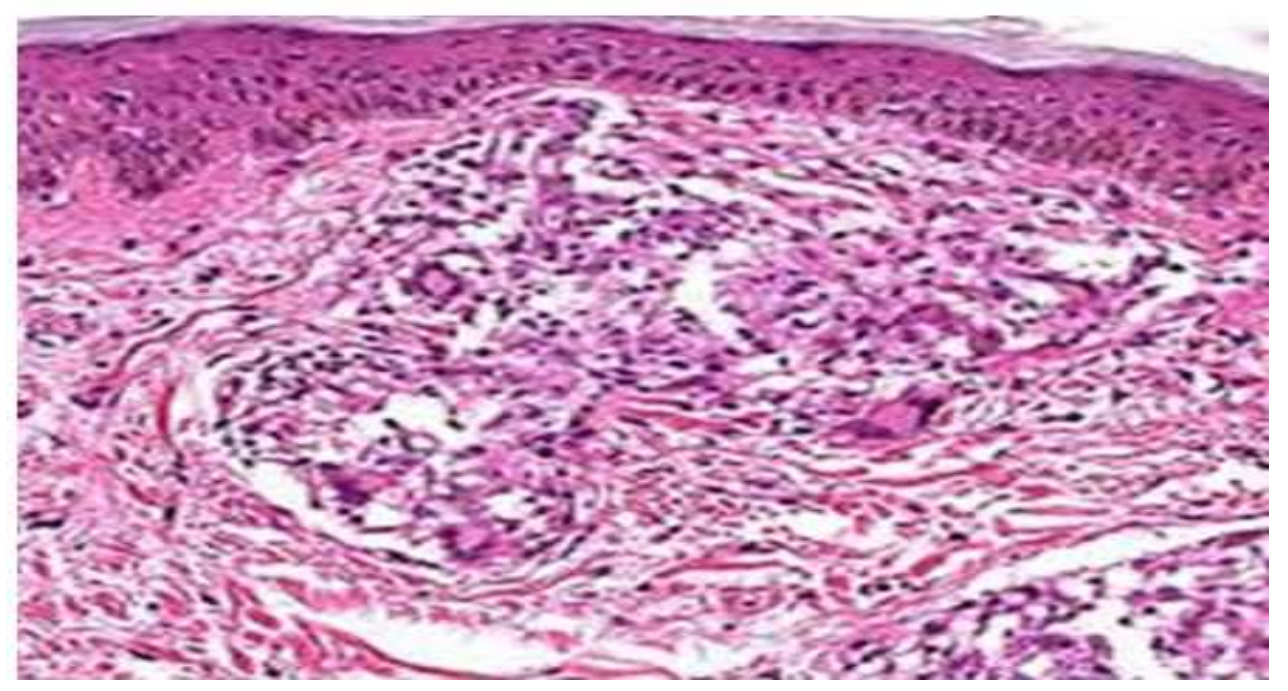

Figure-III: Histopathology of tuberculoid leprosy 


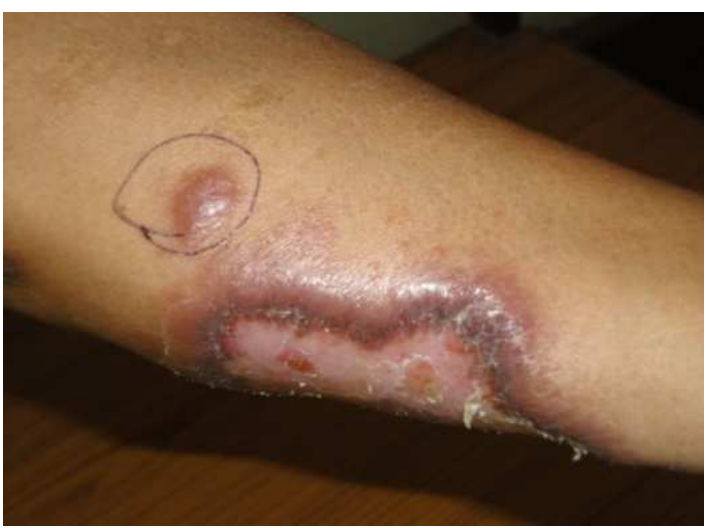

Figure-IV: Clinical case of lepromatous leprosy

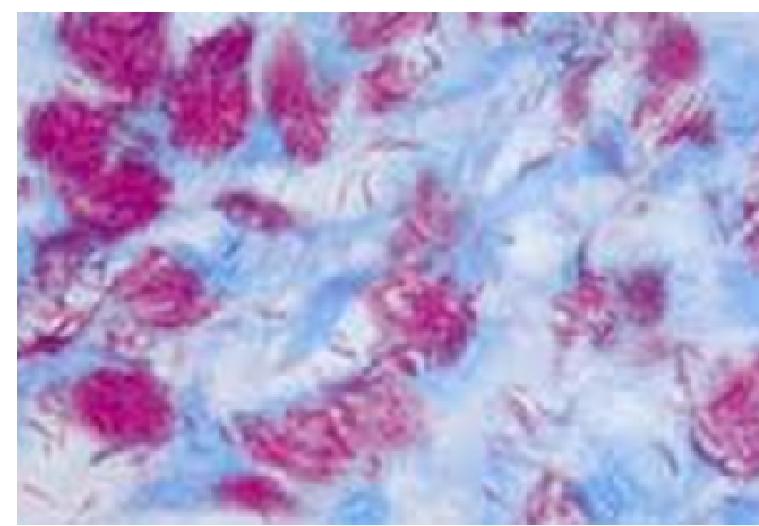

Figure- V AFB BACILLI

According to the RJ classification, 46\% $(\mathrm{n}=23)$ patients were in the borderline spectrum. Borderline Tuberculoid (BT) was the most frequent morphologic type, seen in $32 \%(n=16)$ followed by Tuberculoid leprosy seen in $18 \%(n=9)$, Borderline (BB) in 2\% ( $n=1)$, Borderline Lepromatous (BL) in 12\% $(n=6)$ and Lepromatous (LL) in $12 \%(n=6)$ patients. Additionally, special types of leprosy were recorded in $4 \%$ patients $(n=2)$ with Histoid, and indeterminate forms in 10 (20\%). (FIGURE I, FIGURE III)

On cytological aspiration taken from these patients suggested 11 (22\%) tuberculoid (TT), 6 (12\%) lepromatous, 20 (40\%) borderline including [BT $15(30 \%)$, BB $3(6 \%)$ and BL $2(4 \%)$ ], 2 (4\%) cases of Histoid leprosy on FNAC [Figure-II ]. Out of 50 cases, $11(22 \%)$ cases were reported as unsatisfactory for evaluation on cytology due to insufficient material [TABLE 3]. Considering Clinical diagnosis and FNAC the concordance was as follows; high correlation was seen in all types of leprosy except in Borderline Lepromatus leprosy and complete concordance for FNAC was $64 \%$.

Table-3: Distribution of cases according to cytology diagnosis.

\begin{tabular}{|c|c|c|}
\hline Type of leprosy & No.of cases & Percentage \% \\
\hline Tuberculoid leprosy & 11 & 30 \\
\hline Borderline tuberculoid & 15 & 6 \\
\hline Mid-borderline & 3 & 4 \\
\hline Borderline lepromatus & 6 & 4 \\
\hline Lepromatus leprosy & 2 & 22 \\
\hline Histoid leprosy & 11 & $\mathbf{1 0 0}$ \\
\hline Inadequate & $\mathbf{5 0}$ & \\
\hline Total & & \\
\hline
\end{tabular}

Biopsy records were available for all cases. BT leprosy was the most common histological diagnosis. A clinicohistopathological correlation was observed in 46 out of 50 cases $(92 \%)$ with 4 cases $(8 \%)$ demonstrating non-specific dermatitis features. $100 \%$ correlation between clinical diagnosis and HPR was seen in Tuberculoid leprosy, Borderline tuberculoid, Mid borderline and Histoid leprosy.

In our study we observed maximum parity of both Cytology and Histopathology against the clinical diagnosis in polar groups, tuberculoid and lepromatous. FNAC shows concordance in $8(88 \%)$ for tuberculoid and 4 (66\%) for lepromatous leprosy and histopathology shows concordance in 9 (100\%) for tuberculoid and $5(83.3 \%)$ for lepromatous leprosy. While in borderline groups (BT, BB, BL, ) concordance of FNAC was 18 (36\%) and histopathology was 21(42\%) respectively. This clearly indicates that the FNAC is more useful for polar groups than the borderline cases because of overlapping in the smear findings. Therefore histopathology is better choice over the FNAC in borderline or unstable group of leprosy cases [TABLE 4] 
Table-4: Correlation between clinical and fine needle aspiration cytology diagnosis.

\begin{tabular}{|c|c|c|c|c|c|}
\hline Type of Leprosy & $\begin{array}{c}\text { Clinical } \\
\text { Diagnosis } \\
\mathbf{N}\end{array}$ & FNAC Diagnosis & $\begin{array}{c}\text { Percentage } \\
\text { correlation } \\
\%\end{array}$ & $\begin{array}{c}\text { HPR } \\
\text { DIAGNOSIS }\end{array}$ & $\begin{array}{c}\text { Percentage } \\
\text { correlation } \\
\%\end{array}$ \\
\hline Tuberculoid leprosy & 9 & 11 & 88 & 9 & 100 \\
\hline Borderline tuberculoid & 16 & 15 & 93.7 & 16 & 100 \\
\hline Mid-borderline & 1 & 3 & 100 & 2 & 100 \\
\hline Borderline lepromatus & 6 & 2 & 33 & 4 & 66.6 \\
\hline Lepromatus leprosy & 6 & 6 & 66.6 & 4 & 83.3 \\
\hline Histoid leprosy & 2 & 2 & 100 & 2 & 100 \\
\hline Indeterminate leprosy & 10 & - & - & 9 & 80 \\
\hline Inadequate & & 11 & & & \\
\hline Non-specific dermatitis & & & & 4 & \\
\hline Total & 50 & 50 & & & \\
\hline
\end{tabular}

Histoid leprosy showed complete concordance $100 \%$ both in FNAC as well as Histopathology accounting to its unique cytological features of elongated spindle shaped cells along with scattered lymphocytes and bacillary index of 6+. Indeterminate leprosy was diagnosed histologically in 10 cases, out of which 3 showed features of Tuberculoid spectrum, 2 showed features of Lepromatus spectrum while five cases had insufficient cellularity for evaluation.

Table- 5: Diagnostic Performances of Cytology and Histopathology.

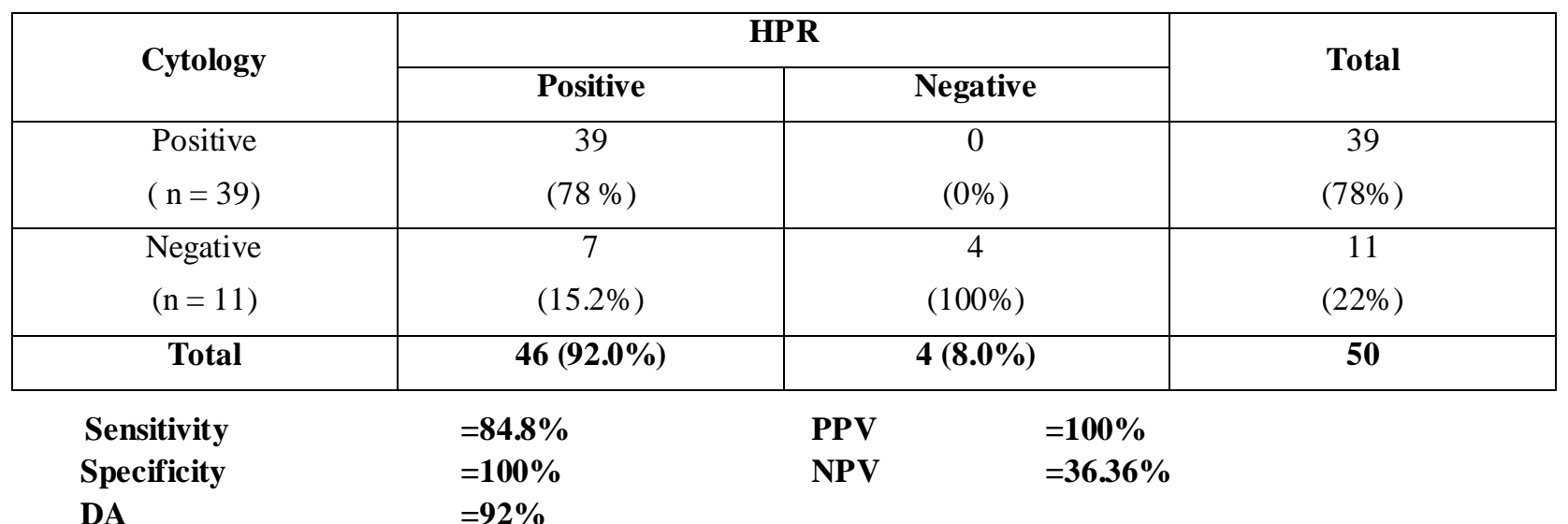

On correlating cytological and histopathological results of the cases, it showed that out of 50 FNAC which were performed diagnosis were possible in 39 cases $(78 \%)$ and $11(22 \%)$ were negative. HPR results of these 50 cases showed definite results were seen in $46(92 \%)$ and $4(8 \%)$ were negative.

Out of these 46 positive cases of HPR, FNAC confirmed positive results in $39(84.8 \%)$ cases and 7 (15.2\%) cases were negative. While out of the 4 negative HPR reports, FNAC confirmed negative results for all $4(100 \%)$ cases. Thus the sensitivity of the FNAC over HPR was found $84.8 \%$. Specificity $100 \%$, positive predictive value was observed at $100 \%$ and negative predictive value at $36 \%$. The overall diagnostic accuracy was found at $92 \%$. [Table 5]

\section{Discussion}

Present study comprises fifty clinically newly diagnosed cases of Hansen's disease. All the patients were investigated by fine needle aspiration cytology and biopsy for histological assessment.
In the present study of 50 cases, age ranged from 8 yrs to $70 \mathrm{yrs}$ with the mean age 38.06 years. Most patients belonged to 20-40 yrs of age. Similar age incidence was reported by Prasad P, George RV et al [8] in year 2008. 
Age incidence of present series favorably simulates with the age incidence reported by Jindal et al [11], who also observed maximum number of cases $47.8 \%$ in 21 40 years.

In our study, 50 cases of both the sexes were included there were $35(70 \%)$ males and $15(30 \%)$ females and the ratio of male and female was $7: 3$, showing a male predominance. Sex incidence of our study favorably simulates study of Prasad P., George RV et al [8] where male female ratio of 2.4:1 and Rao et al reported $5: 1[12]$. Male predominance may be because of many factors such as industrialization, urbanization and more opportunities for contact in males, social customs and taboos may account for the smaller number of females reporting for treatment to the hospital [19].

In present study, clinically $46 \%(\mathrm{n}=23)$ patients were in the borderline spectrum. Borderline Tuberculoid (BT) was the most frequent morphologic type, seen in $32 \%(\mathrm{n}=16)$ the observations were similar to observations made by Prasad PVS et al [8]. Sheoni et al, [13] Moorthy et al [14].

In our study, correlation of clinical diagnoses with cytology (FNAC) is noticed in $88 \%$ of tuberculoid leprosy, $93.7 \%$ of borderline tuberculoid, $33 \%$ of borderline lepromatous and $66.6 \%$ of lepromatous leprosy cases. We have found maximum clinicocytological correlation (100\%) in Histoid Leprosy and mid-borderline type. Prasad PVS et al [8] observed maximum clinico-cytological parity in TT $(87.5 \%)$, BT $(92.1 \%)$, and BL $(80.9 \%)$, which are similar to our findings.

Literature reveals that the histopathological conformation rate in several studies varies from $29 \%$ to $58 \%$ in early stages of leprosy and clinically [15]. In the present study the histopathological diagnoses were consistent with the clinical diagnoses in 46 out of 50 $(90 \%)$. The percentage of parity between the clinical and histopathological classification was highest at the polar ends of the spectrum. The percentage of concordance was less for the borderline group with least correlation in borderline lepromatous cases in the present study which is comparable to the results of Moorthy et al [14] (2001), Bijjaragi S et al[16] (2012). Histopathology continues to be regarded as the gold standard for the diagnosis; particularly in early stage of Hansen's disease. The histopathological features in Hansen's disease provide complete tissue details for accurate diagnosis. The biopsy features indicate the accurate tissue response while the clinical features indicate only the gross morphology of the lesions caused by the underlying pathology. It also provides information on the nature of host response by which one can predict the likely course of the disease and the likely response to therapy.

The sensitivity of Cytology for diagnosis of various Hansen's disease lesions over Histopathology was found $84.8 \%$ and specificity $100 \%$ in our study. Thus the overall cytodiagnostic accuracy has been $92 \%$ in present study which is similar to study carried by Mehdi $\mathrm{G}$, et al [17] in 2010 who noted $92 \%$ accuracy in the diagnosis of leprosy and it is higher than $81.8 \%$ reported by T.S Jaswal, et al [18] in 2001. This could be due to proper selection of cases with full blown clinical picture. It was seen that histopathology features provided more accurate diagnosis of Hansen's disease skin lesions; however diagnosis takes a longer time as compared to the early diagnosis provided by cytology. The study highlights the importance of FNAC and biopsy as an aid in diagnosis and classification.

\section{Conclusion}

The cytological study (FNAC) in Hansen's disease skin lesions provides an accurate provisional diagnosis in the majority of cases; especially in polar (stable type) leprosy. It is a minimally invasive, requires very little expertise and can be performed as an outpatient department procedure. Therefore, FNAC should be routinely employed, whenever facilities of biopsy are not available or patient is unwilling for biopsy. Correlation of clinical and cytopathological features along with bacteriological index appears more useful for accurate typing of Hansen's disease than considering any of the single parameters alone. This helps the clinician for better care and management of patients.

Funding: Nil, Conflict of interest: None initiated, Permission from IRB: Yes

\section{Referances}

1. WHO. Weekly epidemiological record. In: WHO, eds. WHO Record No.34.Geneva:WHO;2012: 317-328.

2. NLEP. Progress report for the year 2012-13 ending on 31 st March 2013. In: NLEP, eds. NLEP Report. New Delhi: Central Leprosy Division, Directorate General of Health Services; 2012. 
3. Shantaram B, Yawalkar SJ. Leprosy-differential diagnosis. In: Valia RG, Valia AR, eds. Textbook and Atlas of Dermatology. 2nd ed. Bombay: Bhalani Publishing House; 1994: 1385-91.

4. Bhatia AS, Katoch K, Narayanan RB, Ramu G, Mukherjee A, Lavania RK. Clinical and histopathological correlation in the classification of leprosy. Int J Lepr Other Mycobact Dis. 1993 Sep; 61(3):433-8.

5. Ridley DS, Jopling WH. Classification of leprosy according to immunity. A five-group system. Int J Lepr Other Mycobact Dis. 1966 Jul-Sep;34(3):255-73.

6. Ridley DS. Histological classification and the immunological spectrum of leprosy. Bull World Health Organ. 1974;51(5):451-65.

7. World Health Organization (WHO). Chemotherapy of leprosy for control programmes. In: WHO, eds. WHO Technical Report Series, no. 675. Geneva: World Health Organization; 1982: 8-33.

8. Prasad PV, George RV, Kaviarasan PK, Viswanathan P, Tippoo R, Anandhi C. Fine needle aspiration cytology in leprosy. Indian J Dermatol Venereol Leprol. 2008 Jul-Aug;74(4):352-6.

9. Singh N, Bhatia A, Gupta K, Ramam M. Cytomorphology of leprosy across the Ridley-Jopling spectrum. Acta Cytol. 1996 Jul-Aug;40(4):719-23.

10. Watts JC, Chandler FW. The surgical pathologists' role in the diagnosis of infectious diseases. J Histotechnol. 1995;18:191-3. [DOI via Crossref].

11.Jindal N, Shanker V, Tegta GR, Gupta M, Verma GK. Clinico-epidemiological trends of leprosy in Himachal Pradesh: a five year study. Indian J Lepr. 2009 Oct-Dec;81(4):173-9.
12. Rao IS, Singh MK, Gupta SD, Pandhi RK, Kapila K. Utility of fine-needle aspiration cytology in the classification of leprosy. Diagn Cytopathol. 2001 May;24(5):317-21.

13. Shenoi SD, Siddappa K. Correlation of clinical and histopathologic features in untreated macular lesions of leprosy--a study of 100 cases. Indian J Lepr. 1988 Apr;60(2):202-6.

14. Moorthy BN, Kumar P, Chatura KR, Chandrasekhar HR, Basavaraja PK. Histopathological correlation of skin biopsies in leprosy. Indian J Dermatol Venereol Leprol. 2001 Nov-Dec;67(6):299-301.

15. Reja AH, Biswas N, Biswas S, Dasgupta S, Chowdhury IH, Banerjee S, et al. Fite-Faraco staining in combination with multiplex polymerase chain reaction: a new approach to leprosy diagnosis. Indian J Dermatol Venereol Leprol. 2013;79:693-700. [DOI via Crossref] [Pubmed]

16. Bijjaragi S, Kulkarni V, Suresh KK, Chatura KR, Kumar P. Correlation of clinical and histopathological classification of leprosy in post elimination era. Indian $\mathbf{J}$ Lepr. 2012 Oct-Dec;84(4):271-5.

17. Mehdi G, Maheshwari V, Ansari HA, Saxena S, Sharma R. Modified fine needle aspiration technique for diagnosis of granulomatous skin lesions with special reference to leprosy and cutaneous tuberculosis. Diagn Cytopathol. 2010;38(6):391-6. [Pubmed]

18. Jaswal TS, Jain VK, Jain V, Singh M, Kishore K, Singh S. Evaluation of leprosy lesions by skin smear cytology in comparison to histopathology. Indian $\mathbf{J}$ Pathol Microbiol. 2001 Jul;44(3):277-81.

\section{How to cite this article?}

Nandwani R.R, Krishnan M.G, Gupta U, Jain M. Clinical and cyto-histopathological study of Hansen's disease in teaching government hospital in Mahakausal Region. Int J Med Res Rev 2016;4(9):1713-1721.doi:10.17511/ijmrr. 2016.109.33. 